\title{
Ultrastructure of ovarian follicular epithelium of the amazonian fish Pseudotylosurus microps (Gunther) (Teleostei, Belonidae). I. The follicular cells cycle of development
}

\author{
Carminda da Cruz-Landim ${ }^{1}$ \\ Maria Alice da Cruz-Hofling ${ }^{2}$
}

\begin{abstract}
The present paper deals with the changes on ultrastructural features of the follicular cells along the growth of the oocyte of Pseudotylosurus microps (Gunther, 1868). The epithelium pass from single squamous to pseudostratified and finally cylindric. Remarkable are the changes in the nuclear shapes, the increasing amount of rough endoplasmic reticulum and the formation of large lipid deposits in the follicular cells by the end of vitellogenic phase. Very peculiar intercellular deposits forms between the perinucleolar and vitellogenic phase of oocyte maturation. Although largely referred to in the specialized literature, our attempts to correlate the follicular cells changes with the formation of the oocyte envelopes or even with an endocrine function are not supported by conclusive evidences in the present paper.

KEY WORDS. Pseudotylosurus microps, follicular epithelium, ultrastructure, teleost
\end{abstract}

The ovarian follicular covering has been demonstrated to be a very important part during oocyte growth in a number of different classes of animals. The dynamic aspect of its structure along oogenesis largely suggests that specific functional interrelationships between follicle cells and oocyte may exist prior, during, and eventually after oocyte maturation. Among the fishes a number of functions have been attributed to the follicle cells, as in the production of the components of the chorion of the egg (CHAUDRY 1956; ANDERSON 1967; WOURMS \& SHELDON 1976; SHACKLEY \& KING 1977; LOPES et al. 1982; CRUZ-LANDIM \& CRUZ-HÖFLING 1989a,b, 1999a,b; HYLLNER \& HAUX 1992), in the production of the glycoproteic coat of the mature oocyte (BUSSON-MABILLOT 1977; CRUZ-HöFLING \& CRUZ-LANDIM 1993), in the synthesis of ornamentous structures characteristic of eggs of certain species (ANDERSON 1966, 1974; FLÜGEL 1967; WOURMS \& SHELDON 1976; BUSSON-MABILlOT 1977; DUMONT \& BRUMMETT 1980; HART et al. 1984; CRUZHÖFLING \& CRUZ-LANDIM 1993), in vitellogenesis (HIROSE 1972), in steroidogenesis (LAMBERT 1970; IWASAKI 1973; TANG et al. 1975; KHOO 1975), and in the transformation into a tough protective shell (SHELDON 1978). Although the physiological importance of the follicular epithelium during the gamete growth has been inferred from their close proximity to this highly differentiated cell: that is, the oocyte, a well-defined role is not yet firmly established for such an epithelium.

1) Departamento de Biologia, Instituto de Biociências, Universidade Estadual Paulista. 13506-900 Rio Claro, São Paulo, Brasil.

2) Departamento de Histologia e Embriologia, Instituto de Biologia, Universidade Estadual de Campinas. 13083-970 Campinas, São Paulo, Brasil. 
In the present study the ultrastructure of the follicle cells of Pseudotylosurus microps (Gunther, 1868) was examined in order to add data which could contribute to the knowledege of its functional significance. The present study was undertaken in connection with investigations designed to elucidate the pattern of the vitelline envelope deposition in $P$. microps.

\section{MATERIAL AND METHODS}

Pieces of ovaries from the Amazonian fish Pseudotylosurus microps (Teleostei, Belonidae), were collected from the Solimões River (Manaus, Amazonas), in January. Routine electron microscopy samples were prepared by fixing the pieces in $2,5 \%$ glutaraldehyde in $0,2 \mathrm{M}$ sodium cacodylate, $\mathrm{pH} 7,2$ buffer with $4 \%$ sucrose, post-fixing in 1\% osmium tetroxide in the same buffer; dehydration in encreasing concentration ethanol series and via aceton embbeded in Epon-Araldite resin. The thin sections were stained with uranyl acetate and lead citrate. The examination and photography were made on a Zeiss EM9S2 transmission electron microscope.

\section{RESULTS}

The temporal sequence of follicular epithelium development was determined taking in account the growth phase of oocyte it encloses.

The ovary of $P$. microps is of the asyncronous type containing oocytes in all developmental stages at the same time, which provides a comparative study among the different phases, in the same ovary.

The follicular epithelium around oocytes stages in early perinucleolar phase shows very low cells provided with elongated nuclei, regularly shaped, with heterochromatin lumps apposed to the nuclear envelope, and few cytoplasmic organelles represented mostly by some short profiles of rough endoplasmic reticulum, mitochondria and vesicles filled with low electrondense material (Figs 1,2). In the early stage of the follicle organization the cell apice are apparently interdigitated with the oocyte surface membrane (Fig. 1). Later apical projections are formed toward the peri-oocytic space. A thick, amorphous basal lamina is present which have electron-dense material accumulated in it outer surface. The contacts between neighbouring cells are sinuous, and tight, frequently reinforced by desmosomes (Fig. 2). However at some places, the intercellular spaces are filled with electrondense material (Figs 3,4), that eventually reach the peri-oocytic space where appear as very electrondense dots (Fig. 2A). In addition to the follicular cell apical projections, the peri-oocytic space also contains the oocyte's microvilli, and medium electrondense material, that seems originate from intercellular deposits that shows heterogeneous electrondensities (Fig. 1).

Outside the basal lamina of the follicular epithelium a thecal sheath formed by several circular layers of collagen fibers and fibroblast-like cells are found (Figs $2,5)$.

The oocytes between late perinucleolar phase and early vitellogenesis are surrounded by columnar follicular cells with basal nuclei. As the epithelial cells are tall, thin and have a sinuous lateral outline, in the sections the epithelium gives the impression of being formed for more than one layer of cells. However, although the 


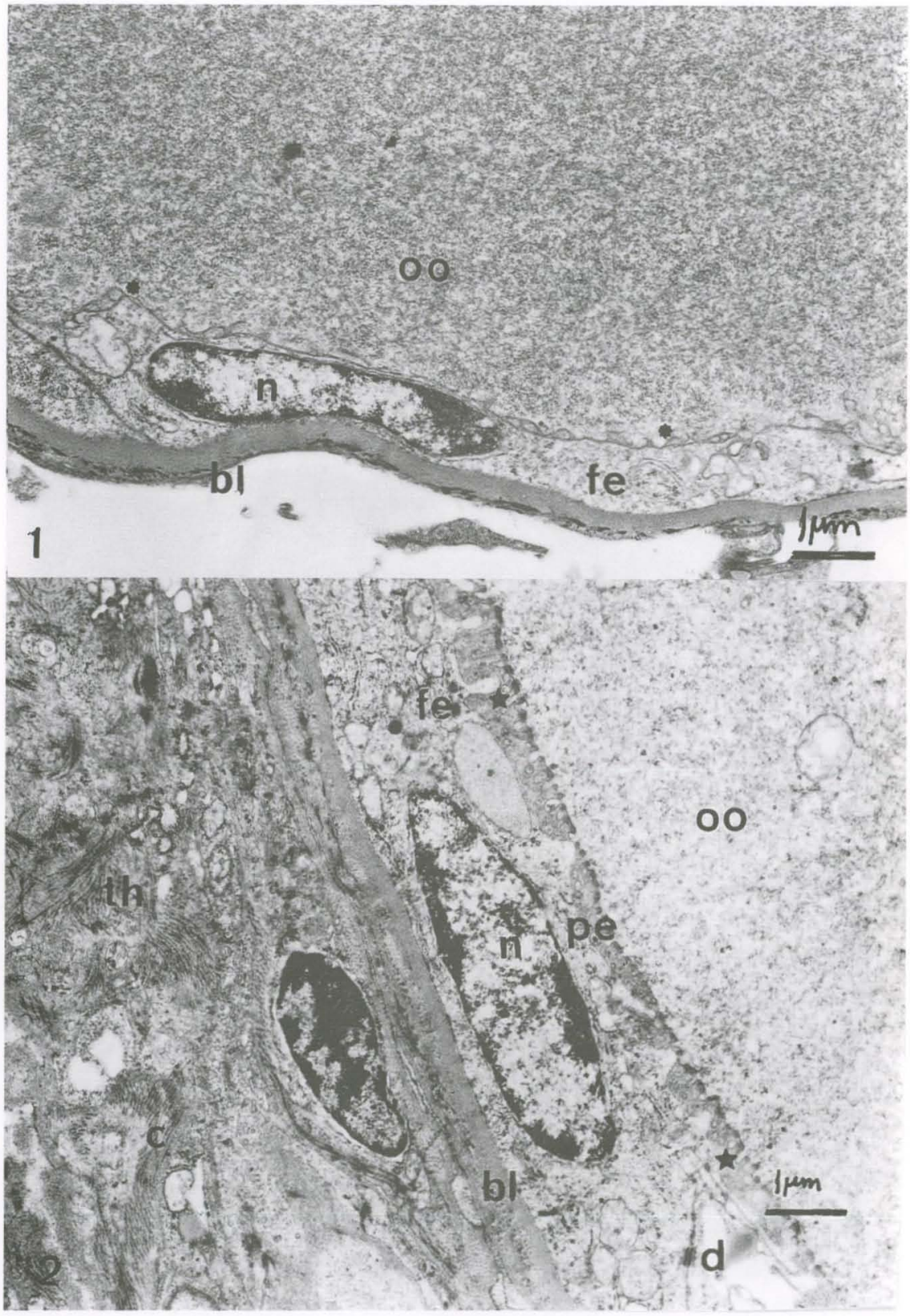

Figs 1-2. (1) Follicular epithelium (fe) around oocyte (oo) in early perinucleolar phase. Notice the apical interdigitations (asteristic) and the electrondense material outside the basal lamina (bl). (2) Notice microvilli and cellular projections (stars) of the follicular cells (fe) and oocyte (oo) throughout the peri-oocytic space (pe). (th) Theca, (c) collagen, ( $n$ ) nuclei. 
sections show more than a membrane limited cytoplasm superposed, the cells nuclei are all basally located, close to the basal lamina, indicating a single layered epithelium. The cells nuclei are nearly spherical, with regular outlines and dispersed chromatin.

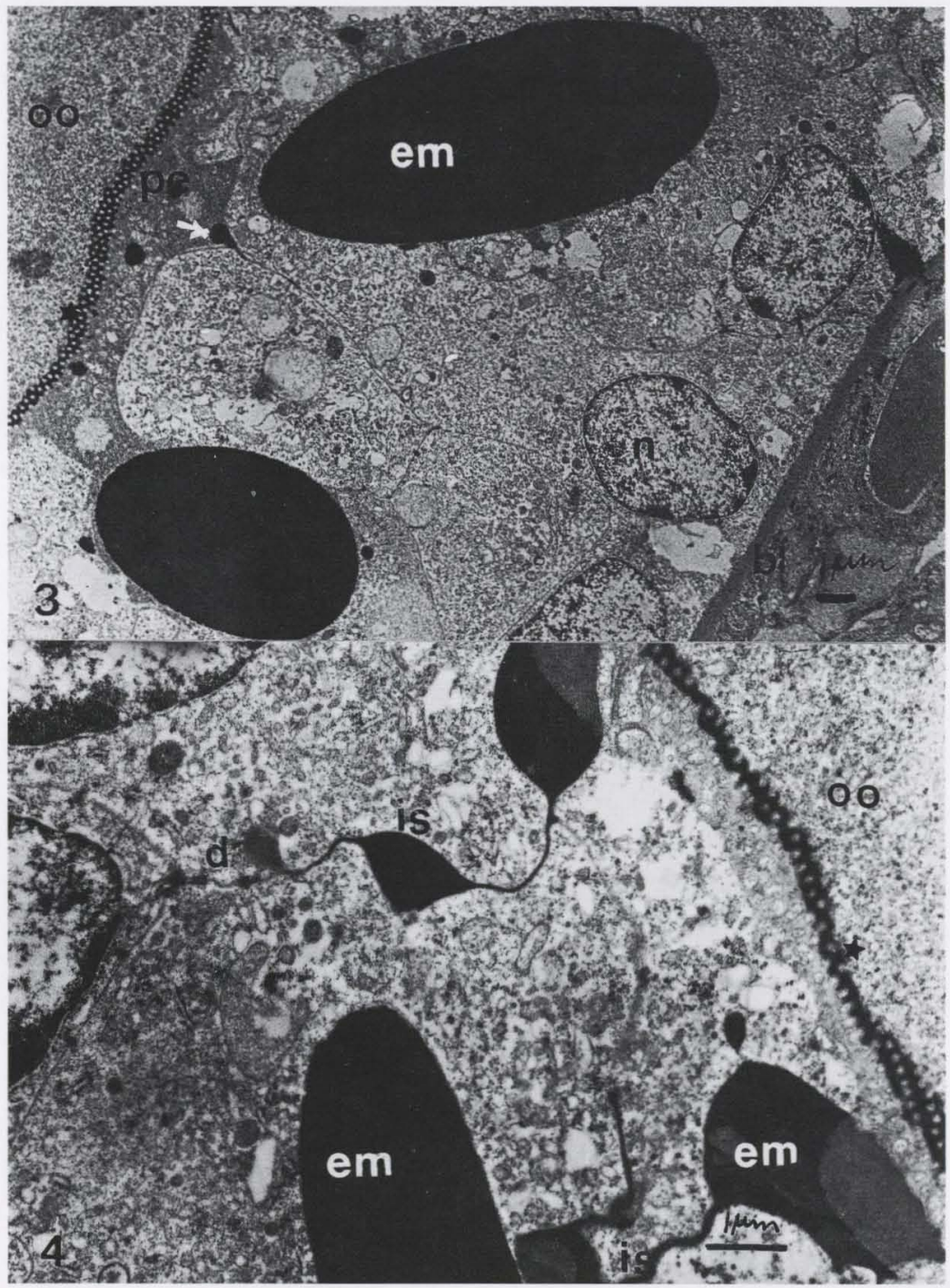

Figs 3-4. (3) Follicular epithelium around late perinucleolar oocyte showing the electron dense masses (em) in the intercellular spaces, and reaching the peri-oocytic space (pe). The basal lamina (bl) is punctuated with small dark dots. (4) Delivery of the material of the electrondense masses (em) into the peri-oocytic space (pe). Notice that at the deliverance site the material acquire the electrondensity of the material that fulfill the space. (is) Intercellular space, (n) nuclei, (d) desmosome, (star) chorion. 
The basal lamina remains thick and present several small dark puntuactions mainly in the outer and inner faces (Fig. 5). Most of the intercellular contacts of the follicle cells, continue to be tight but some of them are filled by extracellular material, which may form small or big masses with different degrees of compactation and electrondensity (Figs 5,6). The presence of the masses promote a great enlargement of the intercellular spaces (Fig. 5). Some of the material in this space present a regular paracrystalline arrangement, whillt others are granular and show zones of lower electrondensity (Figs 3-6).

The location and configuration of this intercellular material indicates that its destination is the peri-oocyte space, where it may be seen reaching in small (Fig. 3) or large (Figs 4, 5) amounts.

Around oocytes in late vitellogenic stage the follicular cells are different of the preceeding stages. In fact the follicular epithelium is still formed by columnar cells, but they are more wide and apparently have less irregular lateral outlines, in such a way that the sections may show one cell from bottom to the apice and the epithelium losses the pseudostratified aspect, to show as typical prismatic (Fig. 7).

The cells are clearly divided in two portions by the nuclei location, which now is central to the cell; a basal and an apical portion. The nuclei are bigger and very irregular in form, showing heterochromatic masses closed to the nuclear envelope and dispersed in the nucleoplasm (Fig. 7). The basal cytoplasm shows extensive deposits of lipid, whose droplets tend to be coalesced, and prominent rough endoplasmic reticulum which tend to be arranged circunferencially around the lipid deposits (Figs 7, 8). The content of the lipid droplets is homogeneously electronlucent. The apical region also present deposits of material whose morphology indicates a lipidic nature, but their form and disposition is quite different from the basal ones. The content of the apical deposits are not homogeneous, presenting zones more and less electrondense in the same droplet. The droplets do not present tendency to coalesce, and are more irregular in form, some being spheroidal, some polyhedric and some lenticular (Fig. 7). The rough endoplasmic reticulum in this region is also well-developed and tend to be located peripherically and their cisternae parallely arrange to the cell height. The intercellular dense bodies, some of them with very big sizes, are still seen among the epithelial cells, but some of the intercelullar spaces, mostly apically are empty or containing membranous debris (Fig. 7). The oocytes enclosed in this type of follicular epithelium present already a well-developed chorion deposited in their surface and the peri-oocytic space almost disappeared. The top of the follicular cells may be applied to the chorionic surface and residues of the dense bodies can also be seen (Fig. 7).

Around the mature oocyte the follicular epithelium begins desintegration. At this phase, a voluminous space is yet oocupyed by the dense bodies among the apparently disrupted epithelial cells (Fig. 9). The epithelial morphology could no more be defined, since only portions of cytoplasm with or without nuclei are seen interspersed with the dense bodies of huge sizes. Some of the cytoplasmic fragments still shows the before mentioned two types of lipid deposits and rough endoplasmic reticulum (Fig. 7). The nuclei again tend to be spherical in shape and their prominent nucleoli, 
as well as the chromatin pattern do not show signs or inactivity. Therefore, although disorganized the follicular epithelium of some follicles does not present special signals of cell resorption process, while in others the cells show these signs (Fig. 10), probably in this case an atresic follicle. An electronlucent coat of loose material constitute the outermost layer of the trilaminar chorion of the mature oocyte.

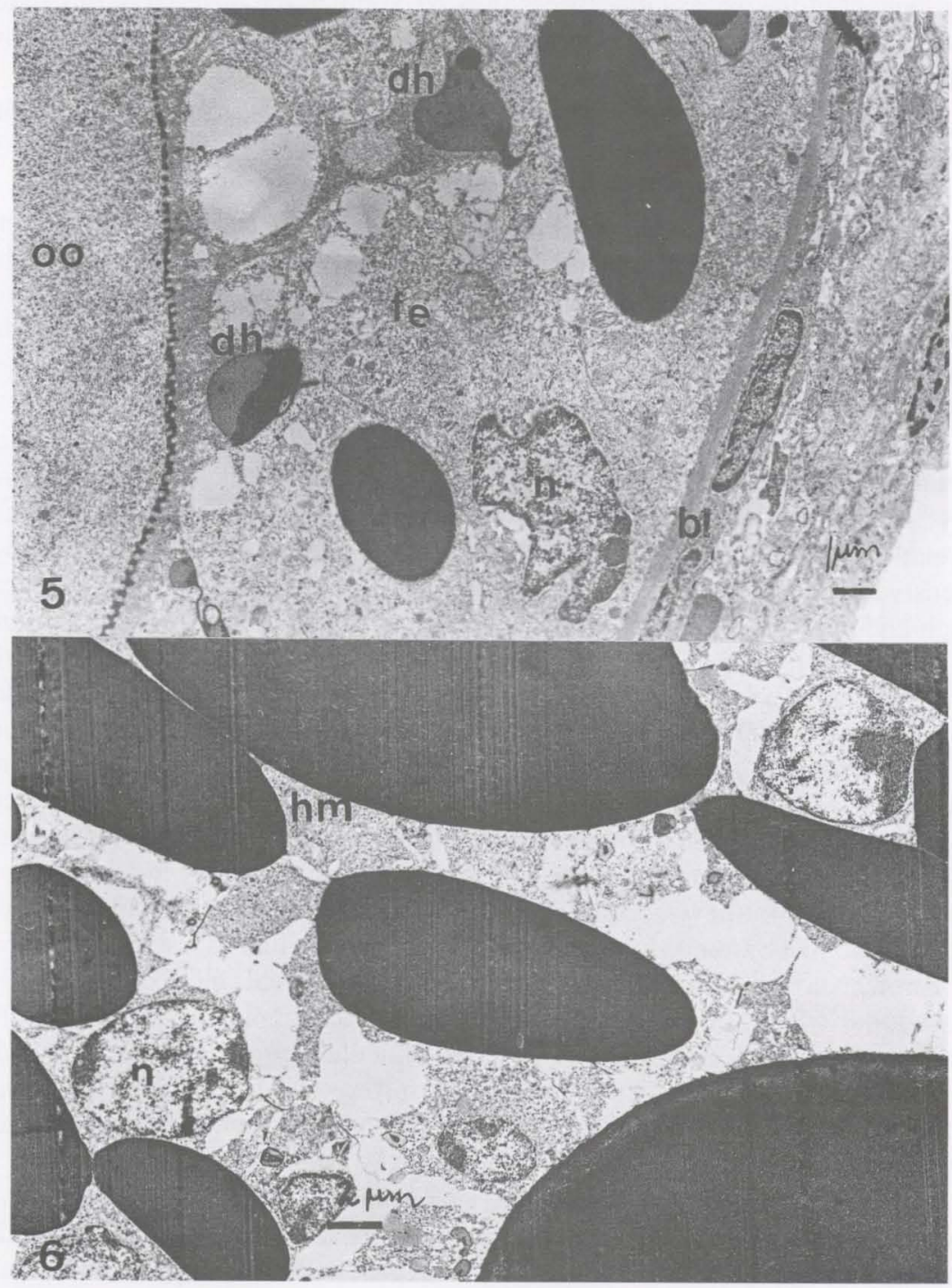

Figs 5-6. (5) Deposition of heterogeneous electrondensities masses (dh) in the follicular cells intercellular spaces. (6) Enlarged intercellular spaces filled with huge globules of homogeneous material (hm). Notice the apparently cellular desorganization. (fe) Follicular epithelium, (bl) basal lamina. 


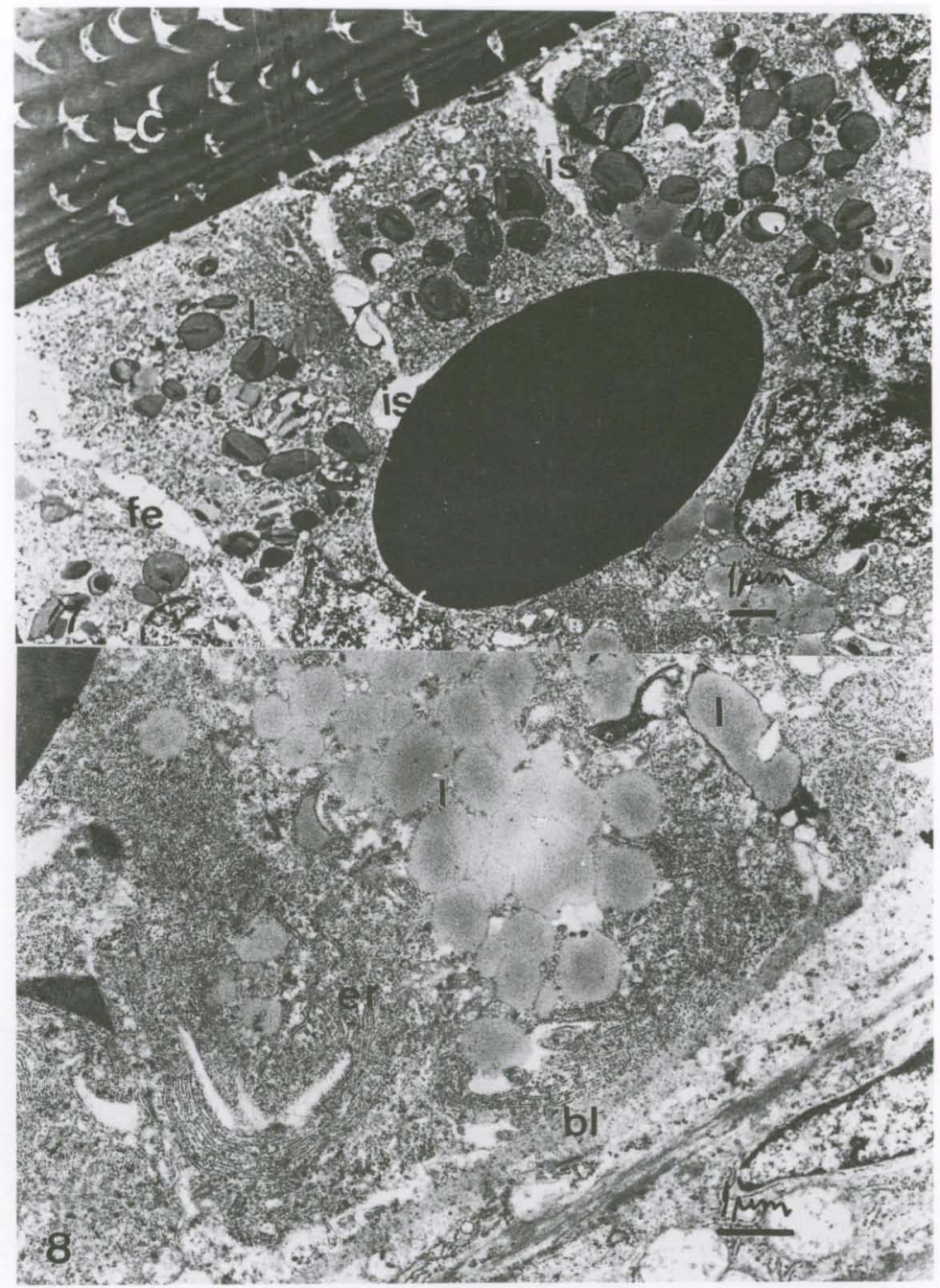

Figs 7-8. (7) Follicular epithelium (fe) around late vitellogenic oocytes showing irregular nuclei $(n)$, lipidic deposits (I). (8) Notice the great development of rough endoplasmic reticulum (er) and the difference between the basal and apical deposits of lipids (I). The basal lamina (bl) still are punctuated by dark dots. (C) Chorion, (is) intercellular space.

\section{DISCUSSION AND CONCLUSIONS}

The developing oocytes of fishes, like those of other vertebrates and invertebrates, are invested by a follicular envelope. In the teleosts there are at least two distinct layers, which by analogy with those of other vertebrates, is sometimes designated as granulosa (follicular epithelium) and theca (outer layer of connective 
tissue). The exact physiological functions of the cells of these layers, remain uncertain, though they have been implicated in yolk proteins transportation from the blood to the oocyte, and oocyte envelope secretion by some authors as that mentioned in the introduction of this paper, and in steroid hormones synthesis, several of which are known to be produced by the teleostean ovaries (NICHOLLS \& MAPLE 1972; LAMBERT 1970; IWASAKI 1973; TANG et al. 1975; KHOO 1975).

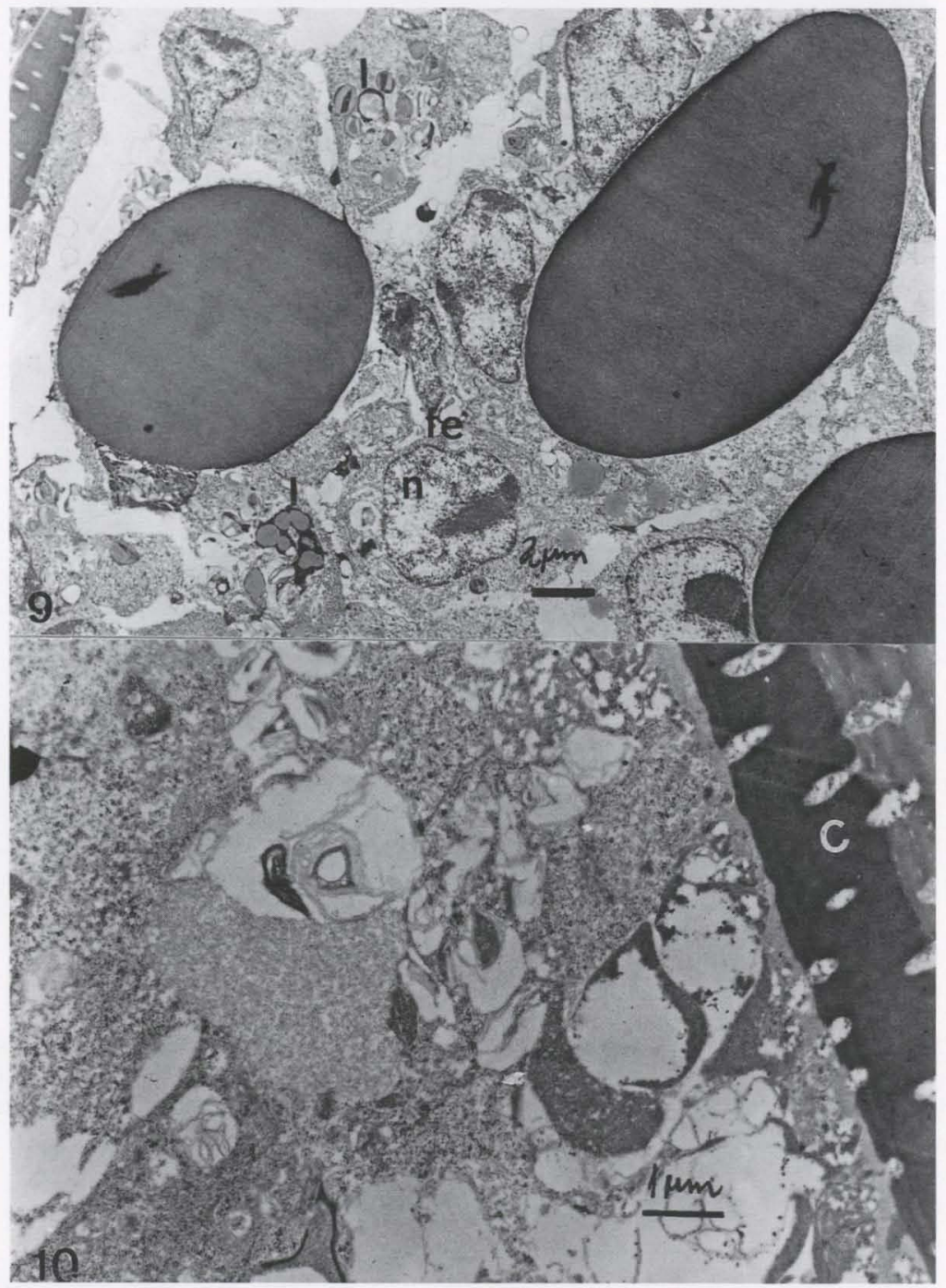

Figs 9-10. Follicular epithelium (fe) disruption around the mature oocyte, showing that the electrondense masses are still present in this phase, and that there are no signs of cellular resorption in 9, but it is present in 10 . (I) Lipid, (n) nuclei, (C) chorion. 
The results of the present study showed that the follicular cells undergo modifications during the oocyte growing phases, but the theca apparently remains unchanged. The follicular epithelium sequentially pass through a squamous, an apparently pseudostratified, and a cylindric form, before finally "desintegrate" by the end of the oogenesis. Some of these modifications may be due to the stretchening promoted by the oocyte growth, but others come along with changes in the nuclei and cytoplasmic features and indicate functional activity modifications. Most relevant seem to be the enlargement of the intercellular spaces, that become fulfilled with polimorphous, generally electrondense bodies of huge size, begining in the perinucleolar phase of oocyte, and the appearance of two types of lipid deposits, distinct from each other by their aspect and localization in the cell, by the end of the vitellogenic phase.

The assigned functions of the follicular epithelium, mentioned above are not so easily connected with these morphological features, but the material that appear in the intercellular spaces, early in the oocyte development, before the beginning of chorion deposition could be yolk precursors.

The oocyte envelope of fishes is usually of glycoproteic nature (CRUZ-LANDIM \& CRUZ-HÖFLING 1989b). Although the follicular cells increase in height during the period of its deposition, and maintain a somewhat well developed rough endoplasmic reticulum, clear involvement of these cells with the chorion secretion was not evident. A Golgi complex was not seen, neither the intracisternal wide spaces, or secretory granules formation in the cytoplasm. The only structures to which some secretory role could be atributed are the few vesicles which contain material of electrondensity identical to that present in the dense bodies present in the perioocytic space. Therefore, in spite of the role attributed to the follicular cells in the formation of oocyte envelopes in a great range of animals, even insects (Britsch 1980; ANDERSON \& SPIELMAN 1971; FAVARD-SERENo 1971, CRUZLANDIM \& CRUZ-HÖFLING 1989a,b, 1999b), the present results are inconclusive to this concern.

The situation is not much different concerning to the role on the steroidegenesis. It is true that although any smooth endoplasmic reticulum was seen in the follicular cells, they do have lipid droplets in their cytoplasm. It is also evident a differential polarity in these lipidic deposits that appears in follicle epithelium of mature oocytes after the chorion deposition. The morphology of the deposits seems to indicate that the ones in the basal pole of cells are in the accumulation stage, and the ones in the apical pole in the mobilization or delivering stage, since their form is more irregular and the differences in electrondensity suggestive of metabolization. The phase in which the deposits appear in the follicular cells, late vitellogenesis, is consistent with a possible constitution by substances that will actuate in ovulation possibly steroids. However, would be expected the "hormone" deliver in the circulation, which is not indicated by the epithelial morphology. Also, the absence of smooth endoplasmic reticulum make problematic the endogenous production of lipids in this cells.

In fact the evidences of steroidgenesis in the cellular sheaths enclosing the oocytes of the teleost Colossoma mitrei Cuvier, 1818 were observed in the thecal 
cells (CRUZ-LANDIM 1990) or, if in follicular cells, after ovulation (NICHOLS \& MAPLE 1972). Another possibility is that the apical deposits of lipid were not being delivered, but that the deliverance occur when the ovarian follicle is disrupted after the oogenesis is over.

Therefore, there were, suggestions of differential activity of follicular cells during oocyte growth, but, at least from the morphological standpoint, the changes verified could not be clearly connected to specific events of the process. The big masses of material accumulated in the follicular cells intercellular spaces is another feature that deserves to be clarified.

ACKNOWLEDGEMENTS. Identification of the specimens by Dr. Naércio Menezes and Dr. Heraldo Britski is gratefully acknowledged. This work was supported by grants from FAPESP, FINEP, CNPq and FAEP-UNICAMP.

\section{REFERENCES}

ANDERSON, E. 1966. A study of the fibrillar appendages associated with the surface of eggs of the killifish, Fundulus heteroclitus. Anat. Rec. 154: 308-309.

. 1967. The formation of the primary envelope during oocyte differentiation in teleosts. Jour. Cell Biol. 35: 193-212.

- 1974. Comparative aspects of ultrastructure of female gamete. Int. Rev. Cytol. 4 (Suppl): $1-70$.

ANDERSON, W.A. \& A. SPIELMAN. 1971. Permability of the ovarian follicle of Aedes aegypti mosquitos. Jour. Cell Biol. 50: 201-221.

BRITSCH, J. 1980. Ultrastructure de l'épithelium folliculaire et des enveloppes de l'ovocyte chez Lepismachilis targionii (Grassi) (Thysanura: Machilidae). Int. Jour. Insect Morphol. Embryol. 9: $25-40$.

Busson-MaBillot, S. 1977. Un type particulier de sécrétion exocrine: Celui de l'appareil adhésif de l'oeuf d'un poisson téléostéen. Biol. Cellulaire 30: 233-244.

CHAUdRY, H.S. 1956. The origin and structure of the zona pellucida in the ovarian eggs of teleosts. $\mathbf{Z}$. Zellforsch. 43: 478-485.

CRUZ-LANDIM, C. 1990. Aspectos ultra-estruturais das células produtoras de esteróides do ovário de Colossoma mitrei (Teleostei: Characidae). Colóquio da Soc. Brasil. Mic. Eletr.: 255-256.

CRUZ-Landim, C. \& M.A, CruZ-HöFling. 1989a. Electron microscopic studies on the development of the chorion of Astyanax bimaculatus (Teleostei: Characidae). Zool. Jb. Anat. 119: 241-249.

-1989b. Estudo ao microscópio eletrônico da deposição do envoltório do ovócito de peixes. I. Plagiosoium squamosissimus (Teleostei-Scianidae). Naturalia 14: 97-105.

- 1999a. Fine structure of previtellogenic oocytes in Pseudotylosurus microps (Teleostei: Belonidae). Braz. Jour. Morphol. Sci. 16: 167-173.

1999b. Ultrastructure of the oocyte vitelline envelope deposition in the Amazonian fish Pseudotylosurus microps (Teleostei: Belonidae). Acta Microscopica 8: 23-28.

Cruz-Höfling, M.A. \& C. Cruz-Landim. 1993. Differentiation of the follicular epithelium during oocyte growth in the Amazonian fish, Crenicichla johanna (Teleostei: Cichlidae). Zool. Jb. Anat. 123: $59-74$.

Dumont, D. \& R. Brummet. 1980. The vitelline envelope, chorion, and micropyle of Fundulus heteroclitus eggs. Gamete Res. 3: 25-44.

FAVARD-SERENO, C. 1971. Cycles sécrétoires successifs au cours de l'élaboration des enveloppes de l'ovocyte chez le Grillon (Insect, Orthoptere). Rôle de l'appareil de Golgi. Jour. Microscopie 11: 401-424. 
FLÜGEL, H. 1967. Lich-und elektronenmikroscopische untersuchungen an oozyten und eiern einiger knochenfische. Z. Zellforsch. 83: 82-116.

Hart, N.H.; R. Pietri \& M. Donovan. 1984. The structure of the chorion and associated surface filaments in Oryzias evidence for the presence of extracellular tubules. Jour. Exp. Zool. 230: 273-296.

HYLLNER, S.J. \& C. HAUX. 1992. Immunochemical of major vitelline envelope proteins in the plasma and oocytes of the maturing female rainbow trout, Oncorhynchus mykies. Jour. Endocrinol. 135: 303-309.

Hirose, H. 1972. The ultrastructure of the ovarian follicle of medaka Oryzias latipes. Z. Zellforsch. 123: $316-329$.

IWASAKI, Y. 1973. Histochemical detection of - 3 - hydroxysteroid dehydrogenase in the ovary of medaka, Oryzias latipes, during annual reproductive cycle. Bull. Fac. Fish. Hokkaido Univ. 23: 177-184.

Kноо, K.H. 1975. The corpus luteum of gold fish Carassius auratus L. and its functions. Can. Jour. Zool. 53: 1306-1323.

LAMBeRT, J.G. 1970. The ovary of the guppy Poecilia reticulata. The granulosa cells as sites of steroid biosynthesis. Gen. Comp. Endocrinol. 15: 464-476.

Lopes, R.A.; H.S.L. Santos; J.R.V Costa; M.G. Pelizaro \& N. Castagnoli. 1982. Histochemical study of oocyte zona radiata of the lambari Astyanax bimaculatus lacustris - Linnaeus, 1758 (Osteichthyes: Characidae). Zool. Anz. 208: 265-268.

Nichols, T.J. \& G. MAPLE. 1972. Ultrastructural observations on possible sites of steroid biosynthesis in the ovarian follicular epithelium of two species of cichlid fish Cichlasoma nigrofasciatum and Haplochomie multicolor. Z. Zellforsch. 128: 317-335.

SCHACKLEY, S.E. \& P.E. KInG. 1977. Oogenesis in a marine teleost, Blennius pholis L. Cell Tissue Res. 181: $105-128$.

Shelton, W.L. 1978. Fate of the follicular epithelium in Dorosoma petenense (Pisces: Clupeidae). Copeia 2: 237-244.

TANG, F.; S.T.H. Chan \& B. LofTs. 1975. A study on the 3B - and 17B hydroxysteroid dehydrogenase activities in the gonads of Monopterus albus (Pisces: Teleostei) at various sexual phases during natural sex reversal. Jour. Zool. 175: 571-580.

WOURMS, J.P. \& H. SHELDON. 1976. Annual fish oogenesis. II. Formation of the secondary egg envelope. Dev. Biol. 50: 355-366.

Recebido em 28.X.1999; aceito em 29.III.2001. 